\title{
Respon Mahasiswa PGMI Terhadap Kurikulum, Laboratorium, dan Dosen Pada Perkuliahan IPA Di Jurusan PGMI IAIN SURAKARTA
}

\author{
Suyatman \\ Dosen PGMI IAIN Surakarta \\ E-mail :paksuyatman@yahoo.co.id
}

\begin{abstract}
This study aims to determine the response of PGMI students to the curriculum, laboratory and lecturers in the IPA lectures at the PGMI FITK IAIN Surakarta Department. This study is a quantitative descriptive study carried out at the PGMI FITK IAIN Surakarta Department. The population and sample in this study were all students of the PGMI Department. Data collection in this study by questionnaire. Presentation in the form of a pie chart and analysis using percentages.

The conclusions of this study are: 1). $84.13 \%$ of respondents stated that the curriculum in the PGMI Department was able to bring resilient MI teacher candidates. Whereas some small ones, namely $5.87 \%$ of respondents stated that they were not capable, namely in the subject areas of study 2). Most $95.38 \%$ of respondents stated that the Science Course was able to bring qualified MI teacher candidates. While a small portion of $4.62 \%$ of respondents said they were unable and suggested to add courses. 3). Most of them are $85.94 \%$ of respondents stating that the Science Course is relevant to the Science Learning Material in MI. While a small portion of $14.06 \%$ of respondents stated that it was irrelevant on the grounds of the material The Science course was too broad, and the lecture material was too difficult. 4). A small percentage of $3.12 \%$ of respondents stated that the equipment in the PGMI laboratory as a supporting facility in the lecture was sufficient. While most of the $96.88 \%$ respondents stated that they were inadequate, by proposing to add science equipment, mathematical equipment, and Indonesian language equipment. 5). A small $18.75 \%$ of respondents stated that the IPA equipment in the PGMI laboratory as a supporting facility in science courses was sufficient. While most of the $81.25 \%$ of respondents stated that they were inadequate.
\end{abstract}

Keywords: PGMI, Curriculum, Science Laboratory 


\section{Pendahuluan}

Pendidikan Guru Madrasah Ibtida'iyah (PGMI) Fakultas Ilmu Tarbiyah dan Keguruan (FITK) IAIN Surakarta merupakan program studi baru, menerima pendaftaran mahasiswa baru mulai tahun akademik 2014/2015, untuk angkatan pertama, sedangkan angkatan ke dua pada tahun akademik 2015/2016. Jumlah total mahasiswa PGMI 151 orang yang terdistribusi dalam 4 kelas, yaitu kelas 4A 37 mahasiswa, kelas 4B 33 mahasiswa, kelas 2A 42 mahasiswa, dan kelas 2B 39 mahasiswa. (Dokumentasi Jurusan PGMI). Latar belakang pendidikan mahasiswa PGMI sangat bervariasi yaitu dari SMU, SMK, dan MA yang berasal dari jurusan IPA, IPS, elektro, tata busana, multimedia, administrasi, akuntasi, pemasaran, agama, dan otomotif. (Wawancara tgl. 22 Maret 2016).

Dari dua data di atas tampak bahwa kelas PGMI termasuk kelas besar yang berasal dari latar belakang pendidikan dan jurusan yang berbeda. Oleh karena itu, diperlukan kurikulum, dosen, dan laboratorium yang memadai, sehingga mahasiswa mampu mengotimalkan kemampuannya, baik secara kognitif, psikomotor, maupun afektif. Selain itu, di dalam buku Panduan Akadmik FITK IAIN Surakarta Tahun Akademik 2015/2016 disebutkan bahwa "salah satu tujuan dari Jurusan PGMI yaitu menghasilkan temuantemuan inovatif dalam bidang kependidikan dan ke Islaman pada Madrasah Ibtida'iyah (tujuan no.4)." (20015:26).

Tujuan mulia di atas perlu adanya faktor pendukung diantaranya kurikulum yang mampu mengejawantahkan tujuan tersebut, SDM (Sumber Daya Manusia) terutama dosen yang profesonal, serta sarana dan prasarana yang memadai. Kurikulum sudah berusaha dirancang dengan porsi yang memadai, dan para dosen PGMI semua sudah mempunyai pendidikan S2, bahkan beberapa dosen sudah S3, sesuai dengan bidang keilmuannya. Sedangkan sarana dan prasarana secara umum cukup, namun tujuan prodi PGMI tersebut di atas sulit untuk terwujud hanya dengan mengandalkan sarana dan prasarana yang dimiliki pada saat ini, terutama laboratoriumnya.

Dari hasil observasi awal terhadap mahasiswa yang mengikuti perkuliahan IPA yaitu mata kuliah Konsep Dasar IPA dan IPA MI, diantara mahasiswa mengusulkan adanya pembenahan laboratorium IPA, perkuliahan IPA didukung dengan percobaan, dan pembelajaran IPA yang lebih riil yang dapat di implementasikan di MI (wawancara, 22 Maret 2016).

Berdasarkan kenyataan tersebut di atas, peneliti ingin menindaklanjutinya dengan meneliti tentang:" Respon Mahasiswa PGMI terhadap Kurikulum, Laboratorium, dan 
Dosen pada Perkuliahan IPA di Jururusan PGMI FITK IAIN Surakarta Tahun 2016" Tujuan dalam penelitian ini yaitu untuk mengetahui respon mahasiawa PGMI terhadap kurikulum, laboratorium dan dosen pada perkuliahan IPA Jurusan PGMI FITK IAIN Surakarta tahun 2016.

Menurut Peraturan Pemerintah Republik Indonesia Nomor 19 Tahun 2005 (PP 19/2005) tentang Standar Nasional Pendidikan, Kurikulum adalah seperangkat rencana dan pengaturan mengenai tujuan, isi dan bahan pelajaran serta cara yang digunakan sebagai pedoman penyelenggaraan kegiatan pembelajaran untuk mencapai tujuan pendidikan tertentu.

Sedangkan, secara garis besar kurikulum di Jurusan PGMI dengan visinya yaitu Menjadi program studi yang unggul ditingkat regional pada tahun 2020 dalam mengembangkan keilmuan dalam bidang pendidikan dan ke-Islaman pada Madrasah Ibtidaiyah yang berakidah kuat, profesional,dan berakhlak mulia. (Pedoman Akademik, 2015: 25).

Adapun misi Jurusan PGMI yang tertuang dalam buku Panduan Akademik dan Kemahasiswaan Tahun Ajaran 2015/2016 sebagai berikut:

1. Menyelenggarakan pendidikan dan pengajaran yang berkarakterke-Islaman, bermutu tinggi, dan berbasis teknologi untuk memenuhi perkembangan kebutuhan madrasah ibtidaiyah di masyarakat.

2. Menyelenggarakan penelitian untuk pengembangan ilmu kependidikan dan ke-Islaman pada jenjang madrasah ibtidaiyah.

3. Menyelenggarakan pengabdian kepada masyarakat untuk pengembangan dan penerapan ilmu kependidikan dan ke-Islaman pada jenjang madrasah ibtidaiyah.

4. Membentuk lingkungan akademik yang Islami dan berbudaya. (Pedoman Akademik 2015: 26)

Sebagai turunan dari adanya visi dan misi berupa mata kuliah yang harus ditempuh mahasiswa sebanyak 65 mata kuliah, yang terdiri 61 mata kuliah wajib dan 4 mata kuliah pilihan. Jumlah totas sks 146 sks yang terdiri dari 138 sks untuk mata kuliah wajib dan 8 sks untuk mata kuliah pilihan. Untuk mata kuliah IPA terdiri dari 6 mata kuliah, seperti pada tabel berikut:

| Volume. 4, No. 1, Januari-Juni 2019 
Respon Mahasiswa PGMI Terhadap Kurikulum, Laboratorium, dan Dosen Pada Perkuliahan IPA Di Jurusan PGMI IAIN SURAKARTA

Tabel 1. Mata Kuliah IPA di Jurusan PGMI

\begin{tabular}{|c|c|c|c|c|}
\hline No & $\begin{array}{c}\text { Kode Mata } \\
\text { Kuliah }\end{array}$ & Nama Mata Kuliah & $\begin{array}{c}\text { Diberikan } \\
\text { Pada Smt }\end{array}$ & Keterangan \\
\hline 1 & PGMI15217 & Konsep Dasar IPA I & 2 & Konsep Dasar Fisika \\
\hline 2 & PGMI15218 & Konsep Dasar IPA II & 3 & $\begin{array}{c}\text { Konsep Dasar } \\
\text { Biologi }\end{array}$ \\
\hline 3 & PGMI15219 & Konsep Dasar IPA III & 4 & Konsep Dasar Kimia \\
\hline 4 & PGMI15231 & IPA MI I & 4 & Materi IPA MI \\
\hline 5 & PGMI15232 & IPA MI II & 5 & $\begin{array}{c}\text { Pembelajaran IPA } \\
\text { di MI }\end{array}$ \\
\hline 6 & PGMI15250 & Pendalaman IPA & 5 & $\begin{array}{c}\text { Mata Kuliah pilihan } \\
\text { Kelompok IPA }\end{array}$ \\
\hline
\end{tabular}

(Sumber: Buku Pedoman Akademik 2015/2016 hal. 86-90)

Dari tabel di atas menunjukan sebagian mata kuliah wajib mahasiswa Jurusan PGMI, yang semuanya terdiri dari 2 sks, sehingga total 12 sks.

\section{Laboratorium}

Secara sempit laboratorium diartikan sebagai ruangan yang dibatasi oleh dinding yang di dalamnya terdapat alat-alat dan bahan-bahan beraneka ragam yang dapat digunakan untuk melakukan eksperimen (Subiyanto, 1998 : 79). Sudaryanto (1998:2) mendefinisikan laboratorium sebagai salah satu sarana pendidikan, sebagai tempat peserta didik berlatih dan kontak dengan objek yang dipelajari secara langsung, baik melalui pengamatan maupun percobaan.

Lebih lanjut Sudaryanto (1998: 7) menyatakan peranan dan fungsi laboratorium ada tiga, yaitu sebagai (1) sumber belajar, artinya lab digunakan untuk memecahkan masalah yang berkaitan dengan ranah kognitif, afektif, dan psikomotor atau melakukan percobaan, (2) metode pendidikan, meliputi metode pengamatan dan metode percobaan, dan (3) sarana penelitian, tempat dilakukannya berbagai penelitian sehingga terbentuk pribadi peserta didik yang bersikap ilmiah.

Beberapa alasan yang menguatkan peran laboratorium dalam pembelajaran antara lain:

a. Praktikum membangkitkan motivasi belajar. Dalam belajar, mahasiswa dipengaruhi oleh motivasi. Mahasiswa yang termotivasi untuk belajar akan bersungguh-sungguh dalam mempelajari sesuatu. Melalui kegiatan laboratorium, mahasiswa diberi kesempatan untuk memenuhi dorongan rasa ingin tahu dan ingin bisa. Prinsip ini akan 
menunjang kegiatan praktikum di mana mahasiswa menemukan pengetahuan melalui eksplorasi.

b. Praktikum mengembangkan keterampilan dasar melakukan eksperimen. Kegiatan eksperimen merupakan aktivitas yang banyak dilakukan oleh ilmuwan. Untuk melakukan eksperimen diperlukan beberapa keterampilan dasar seperti mengamati, mengestimasi, mengukur, membandingkan, memanipulasi peralatan laboratorium, dan ketrampilan sains lainnya. Dengan adanya kegiatan praktikum di laboratorium akan melatih mahasiswa untuk mengembangkan kemampuan bereksperimen dengan melatih kemampuan mereka dalam mengobservasi dengan cermat, mengukur secara akurat dengan alat ukur yang sederhana atau lebih canggih, menggunakan dan menangani alat secara aman, merancang, melakukan dan menginterpretasikan eksperimen.

c. Praktikum menjadi wahana belajar pendekatan ilmiah. Para ahli meyakini bahwa cara yang terbaik untuk belajar pendekatan ilmiah adalah dengan menjadikan mahasiswa sebagai ilmuwan. Pembelajaran sains sebaiknya dilaksanakan melalui pendekatan inkuiri ilmiah (scientific inquiry) untuk menumbuhkan kemampuan berpikir, bekerja dan bersikap ilmiah serta mengkomunikasikannya sebagai aspek penting kecakapan hidup. Oleh karena itu pembelajaran sains mulai dari tingkat dasar sampai perguruan tinggi menekankan pada pemberian pengalaman belajar secara langsung melalui penggunaan dan pengembangan keterampilan proses dan sikap ilmiah.

d. Praktikum menunjang materi pelajaran. Praktikum memberikan kesempatan bagi mahasiswa untuk menemukan teori, dan membuktikan teori. Selain itu praktikum dalam pembelajaran sains dapat membentuk ilustrasi bagi konsep dan prinsip sains. Dari kegiatan tersebut dapat disimpulkan bahwa praktikum dapat menunjang pemahaman mahasiswa terhadap materi pelajaran. (Rustaman, 1995).

\section{Metodologi Penelitian}

Metode penelitian menggunakan pendekatan diskriptif kuantitatif. Penelitian kuantitatif menekankan analisisnya pada data-data numerikal (angka) yang diolah dengan metode statistika. (Saifuddin Azwar, 2013: 5). Dalam penelitian ini data yang akan didiskripsikan yaitu respon mahasiswa PGMI terhadap kurikulum, laboratorum dan dosen Jurusan PGMI.

| Volume. 4, No. 1, Januari-Juni 2019 


\section{Tempat Dan Waktu Penelitan}

Penelitian ini akan dilaksanakan di Jurusan PGMI FITK IAN Surakarta dan waktu penelitian direncanakan 21 April - 20 Juni 2016.

\section{Populasi dan Sampel}

Populasinya seluruh mahasiswa Jurusan PGM yang telah menempuh mata kuliah Konsep Dasar IPA dan IPA MI yang berjumlah 70 mahasiswa. Seluruh populasi dijadikan sampel yaitu 70 mahasiswa, karena penelitian diskriptif.

\section{Teknik Pengumpulan Data}

Teknik pengumpulan data dengan angket. Angket digunakan untuk mengumpulkan data tentang respon mahasiswa PGMI terhadap kurkulum, laboratorium, dosen.

\section{Instrumen Pengumpul Data}

\section{a. Definisi Konsep}

Respon mahasiswa PGMI terhadap kurikulum, laboratorum dan dosen adalah reaksi atas stimulus yang terjadi dalam berinteraksi antara pelakunya dengan mendapatkan rangsangan dari suatu perilaku yang memicu individu atau kelompok untuk bersikap baik itu dengan tindakan atau tanpa tindakan terhadap kurikulum, laboratorum dan dosen.

\section{b. Definisi Operasional}

Respon mahasiswa PGMI terhadap kurikulum, laboratorum dan dosen adalah jawaban respon mahasiswa PGMI terhadap kurikulum, laboratorum, dan dosen dalam perkulahan IPA melalui angket yang diedarkan.

c. Kisi-Kisi

Tabel 2. Kisi-Kisi Angket

\begin{tabular}{|c|c|c|c|}
\hline Variabel & Aspek & Indikator & No. Aitem \\
\hline \multirow{8}{*}{$\begin{array}{l}\text { Respon } \\
\text { mahasiswa } \\
\text { PGMI }\end{array}$} & \multirow[b]{2}{*}{ Kurikulum } & $\begin{array}{l}\text { Relevansinya kurikulum PGMI } \\
\text { dengan kebutuhan lapangan }\end{array}$ & 1,2 \\
\hline & & $\begin{array}{l}\text { Relevansinya mata kuliah IPA } \\
\text { dengan pembelajaran IPA di MI/ } \\
\text { SD }\end{array}$ & $3,4,5,6$ \\
\hline & \multirow{2}{*}{ Laboratorium } & $\begin{array}{l}\text { Keterpenuhan LAB PGMI untuk } \\
\text { media perkuliahan }\end{array}$ & 7,8 \\
\hline & & $\begin{array}{l}\text { Keterpenuhan LAB IPA untuk } \\
\text { percobaan IPA }\end{array}$ & 9,10 \\
\hline & \multirow{4}{*}{ Dosen } & Kompetensi Pedagogik & 11,12 \\
\hline & & Kompetensi Kepribadian & 13,14 \\
\hline & & Kompetensi Profesional & 15,16 \\
\hline & & Kompetensi Sosial & 17,18 \\
\hline
\end{tabular}




\section{d. Teknik Analisis Data}

Analisis data respon mahasiswa PGMI terhadap kurikulum, laboratorium, dan dosen menggunakan analisis persentase. Untuk menghitung persentase suatu jawaban dengan menggunakan rumus sebagai berikut:

$$
\mathbf{P}=\frac{\mathbf{f}}{\mathrm{N}} \times \mathbf{1 0 0} \%
$$

Keterangan: $\mathrm{P}=$ Persentase, $\mathrm{f}=$ frekuensi dari setiap jawaban yang telah menjadi pilihan responden, dan $\mathrm{N}=$ jumlah responden.

\section{Hasil Penelitian dan Pembahasan}

\section{Kurikulum di Jurusan PGMI}

Respon mahasiswa tentang kurikulum di Jurusan PGMI meliputi: Kemampuan Kurikulum membawa calon guru MI yang tangguh, Kemampuan Mata Kuliah IPA membawa calon guru MI yang mumpuni, Relevansi Mata Kuliah IPA dengan Materi Pembelajaran IPA di MI.

a. Kemampuan Kurikulum membawa calon guru MI yang tangguh

Jumlah total jawaban responden 63, yang digambarkan dalam tabel berikut:

Tabel 3. Kemampuan Kurikulum membawa calon guru MI yang tangguh

\begin{tabular}{|c|c|c|c|c|}
\hline No & Aspek & Kreteria & $\begin{array}{c}\text { Jumlah Jawaban } \\
\text { Responden }\end{array}$ & Persentase \\
\hline 1 & \multirow{2}{*}{$\begin{array}{l}\text { Kemampuan } \\
\text { Kurikulum membawa } \\
\text { calon guru MI yang } \\
\text { tangguh }\end{array}$} & Mampu & 53 & $84,13 \%$ \\
\hline 2 & & Tidak Mampu & 10 & $15,87 \%$ \\
\hline \multicolumn{3}{|c|}{ Total } & 63 & $100 \%$ \\
\hline
\end{tabular}

Dari 63 jawaban responden, terdapat 84,13\% responden menyatakan bahwa kurikulum di Jurusan PGMI mampu membawa calon guru MI yang tangguh. Sedangkan 15,87\% responden menyatakan bahwa kurikulum di Jurusan PGMI tidak mampu membawa calon guru MI yang tangguh. Untuk lebih jelasnya disajikan dalam gambar berikut. 


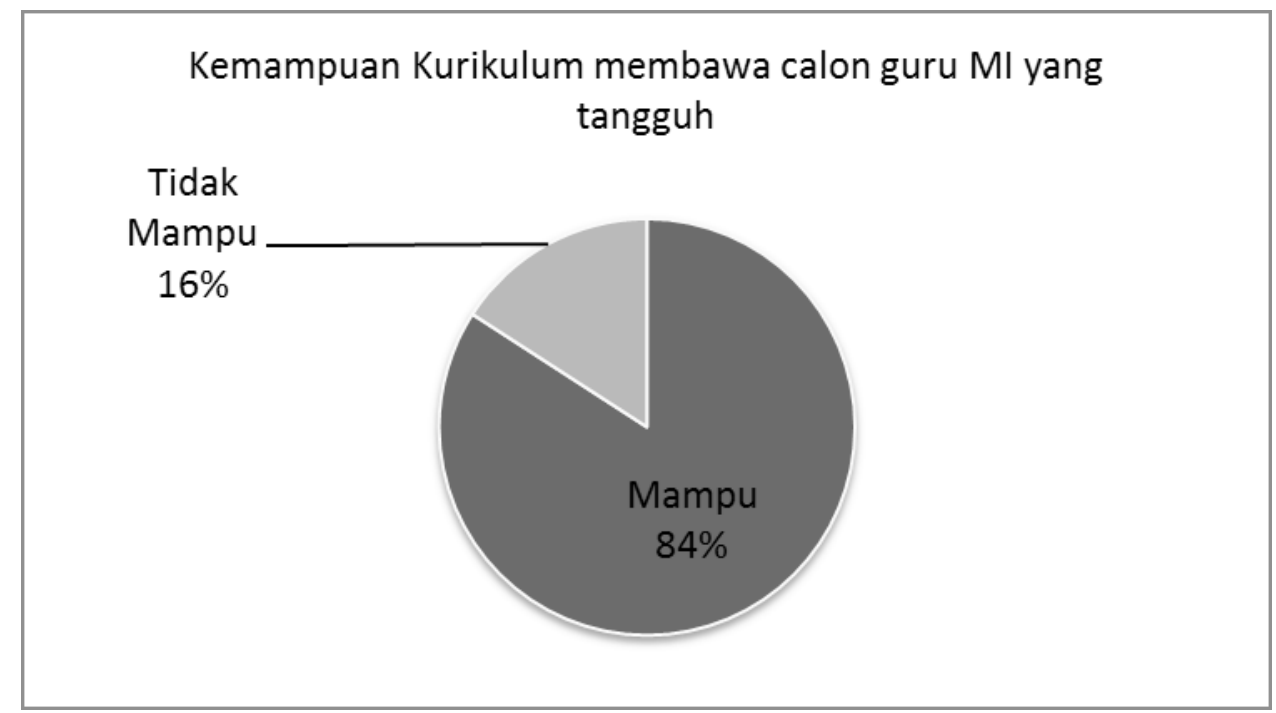

Dari 10 responden yang menyatakan bahwa kurikulum di Jurusan PGMI tidak mampu membawa calon guru MI yang tangguh, 3 responden menyatakan bahwa bagian yang membuat bahwa kurikulum di Jurusan PGMI tidak mampu membawa calon guru MI yang tangguh yaitu pada mata kuliah bidang studi (seperti: IPA, matematika, IPS, PPKn dll), dan 7 responden menyatakan pada bagian mata kuliah keagamaan (Fiqih, SKI, Akhidah, Al-Qur'an dll)

b. Kemampuan Mata Kuliah IPA membawa calon guru MI yang mumpuni

Jumlah total jawaban responden 65 , yang digambarkan dalam tabel berikut:

Tabel 4. Kemampuan Mata Kuliah IPA membawa calon guru MI yang mumpuni

\begin{tabular}{|c|l|l|c|c|}
\hline No & \multicolumn{1}{|c|}{ Aspek } & Kreteria & $\begin{array}{c}\text { Jumlah } \\
\text { Jawaban } \\
\text { Responden }\end{array}$ & Persentase \\
\hline 1 & $\begin{array}{l}\text { Kemampuan Mata Kuliah IPA } \\
\text { membawa calon guru MI yang } \\
\text { mumpuni }\end{array}$ & Mampu & 62 & $95,38 \%$ \\
\cline { 3 - 5 } & Tidak Mampu & 3 & $4,62 \%$ \\
\hline Total & \multicolumn{2}{|l}{} & 65 & $100 \%$ \\
\hline
\end{tabular}

Dari 65 jawaban responden, terdapat 95,38\% responden menyatakan bahwa Mata Kuliah IPA mampu membawa calon guru MI yang mumpuni. Sedangkan 4,62\% responden menyatakan bahwa Mata Kuliah IPA tidak mampu membawa calon guru MI yang mumpuni. Untuk lebih jelasnya disajikan dalam gambar berikut. 


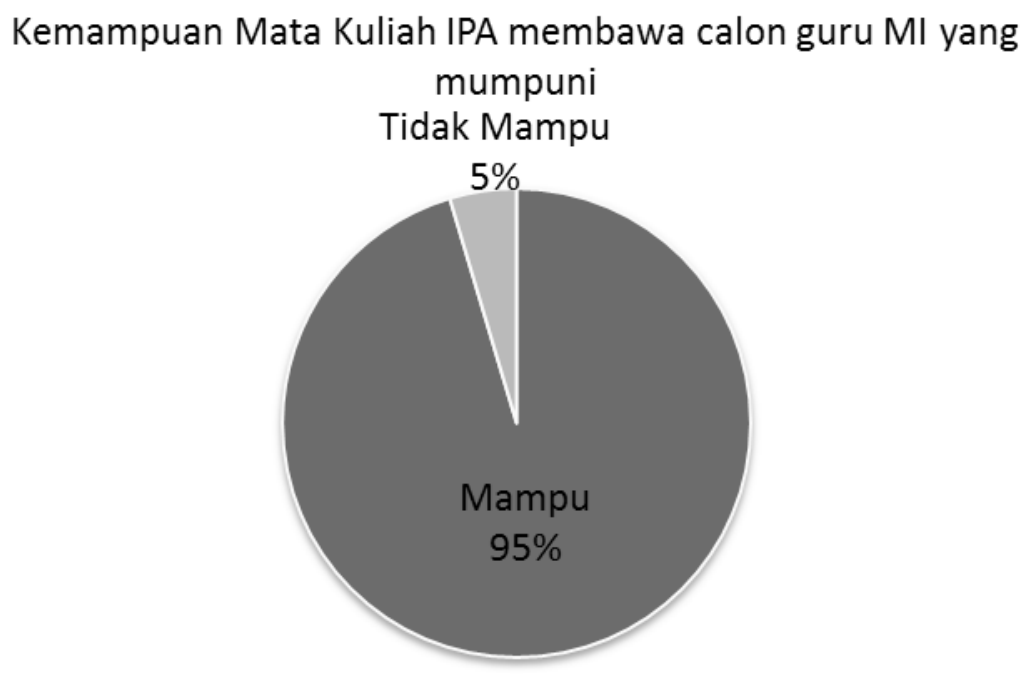

Dari 3 responden yang menyatakan bahwa Mata Kuliah IPA tidak mampu membawa calon guru MI yang mumpuni, 1 responden menyarankan untuk menambah mata kuliah dan 2 responden menyarankan untuk mengurangi mata kuliah.

c. Relevansi Mata Kuliah IPA dengan Materi Pembelajaran IPA di MI.

Jumlah total jawaban responden 64, yang digambarkan dalam tabel berikut:

Tabel 5. Relevansi Mata Kuliah IPA dengan Materi Pembelajaran IPA di MI

\begin{tabular}{|l|l|l|c|c|}
\hline No & Aspek & Kreteria & $\begin{array}{c}\text { Jumlah } \\
\text { Jawaban } \\
\text { Responden }\end{array}$ & Persentase \\
\hline 1 & $\begin{array}{l}\text { Relevansi Mata Kuliah IPA } \\
\text { dengan Materi Pembelajaran } \\
\text { IPA di MI }\end{array}$ & Relevan & 55 & $85,94 \%$ \\
\hline \multicolumn{2}{|l|}{ Tidak Relevan } & 9 & $14,06 \%$ \\
\hline
\end{tabular}

Dari 64 jawaban responden, terdapat 85,94\% responden menyatakan bahwa Mata Kuliah IPA relevan dengan Materi Pembelajaran IPA di MI. Sedangkan 14,06\% responden menyatakan bahwa Mata Kuliah IPA tidak relevan dengan Materi Pembelajaran IPA di MI. Untuk lebih jelasnya disajikan dalam gambar berikut. 
Respon Mahasiswa PGMI Terhadap Kurikulum, Laboratorium, dan Dosen Pada Perkuliahan IPA Di Jurusan PGMI IAIN SURAKARTA

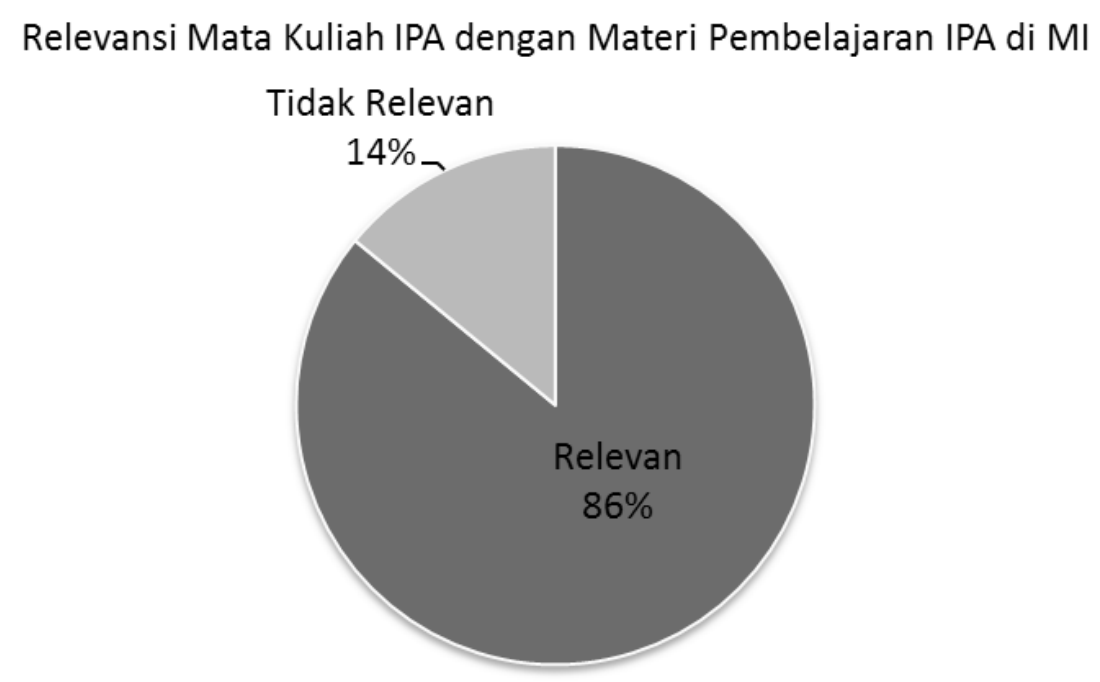

Dari 9 responden yang menyatakan bahwa Mata Kuliah IPA tidak relevan dengan Materi Pembelajaran IPA di MI, 6 responden berasalan materi Mata Kuliah IPA terlalu luas, 1 responden menyatakan bahwa materi kuliah terlalu sulit, dan 2 responden tidak berpendapat.

\section{Laboratorium PGMI}

Respon mahasiswa tentang Laboratorium PGMI meliputi: peralatan yang ada di laboratorum PGMI sebagai sarana pendukung dalam perkuliahan dan peralatan IPA yang ada di laboratorum PGMI sebagai sarana pendukung dalam perkuliahan IPA.

a. Peralatan yang ada di laboratorum PGMI sebagai sarana pendukung dalam perkuliahan.

Jumlah total jawaban responden 64, yang digambarkan dalam tabel berikut:

Tabel 4, Peralatan yang ada di laboratorum PGMI

\begin{tabular}{|l|l|l|c|l|}
\hline No & Aspek & Kreteria & $\begin{array}{c}\text { Jumlah } \\
\text { Jawaban } \\
\text { Responden }\end{array}$ & Persentase \\
\hline 1 & $\begin{array}{l}\text { Peralatan yang ada di } \\
\text { laboratorum PGMI sebagai } \\
\text { sarana pendukung dalam } \\
\text { perkuliahan. }\end{array}$ & Sudah Memadai & 2 & $3,12 \%$ \\
\hline Total & Belum memadai & 62 & $96,88 \%$ \\
\hline
\end{tabular}


Dari 64 jawaban responden, terdapat 3,12\% responden menyatakan bahwa peralatan yang ada di laboratorum PGMI sebagai sarana pendukung dalam perkuliahan sudah memadai. Sedangkan $96,88 \%$ responden menyatakan bahwa peralatan yang ada di laboratorum PGMI sebagai sarana pendukung dalam perkuliahan belum memadai. Untuk lebih jelasnya disajikan dalam gambar berikut.

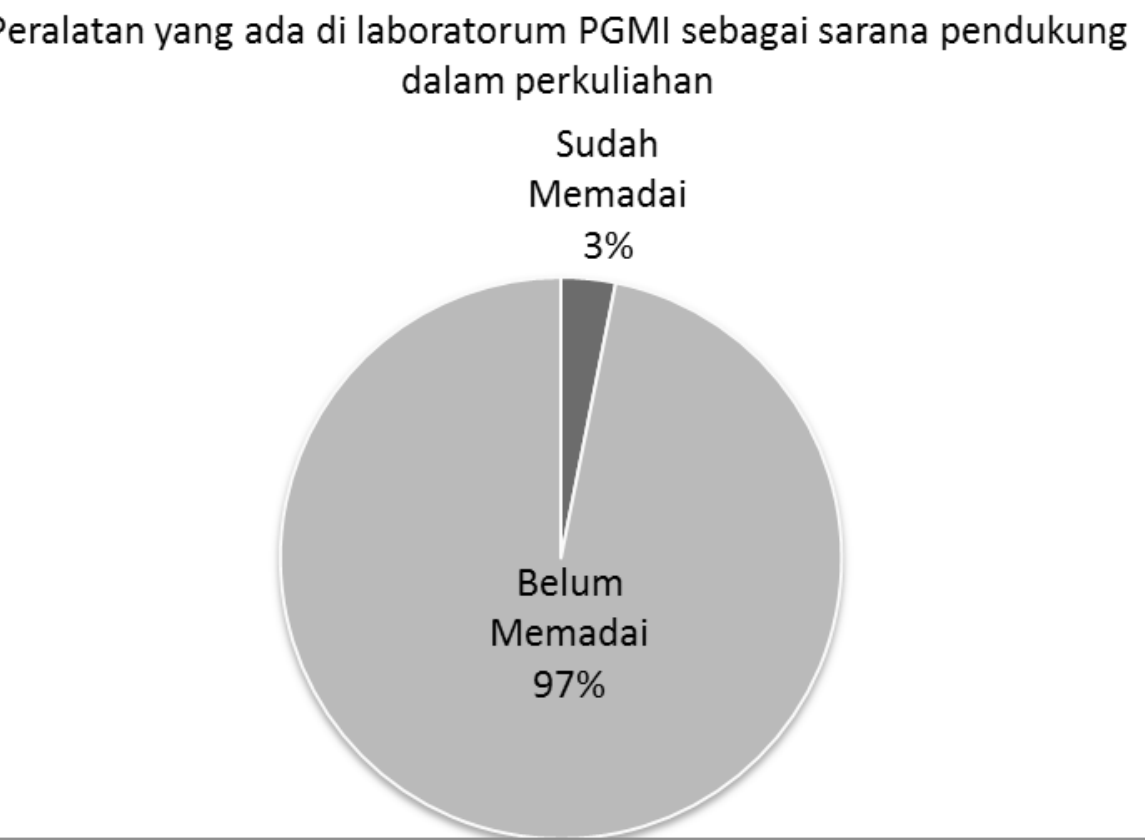

Dari 62 responden yang menyatakan bahwa peralatan yang ada di laboratorum PGMI sebagai sarana pendukung dalam perkuliahan belum memadai, 5 responden mengusulkan untuk menambah peralatan IPS, 12 responden mengusulkan untuk menambah peralatan matematika, 5 responden mengusulkan untuk menambah peralatan bahasa indonesia, dan 40 responden mengusulkan untuk menambah peralatan yang lainnya.

b. Peralatan IPA di laboratorum PGMI sebagai sarana pendukung dalam perkuliahan IPA

Jumlah total jawaban responden 64, yang digambarkan dalam tabel berikut: 
Tabel 5. Peralatan IPA di laboratorum PGMI

\begin{tabular}{|l|l|l|c|l|}
\hline No & Aspek & Kreteria & $\begin{array}{c}\text { Jumlah } \\
\text { Jawaban } \\
\text { Responden }\end{array}$ & Persentase \\
\hline 1 & $\begin{array}{l}\text { Peralatan IPA di laboratorum } \\
\text { PGMI sebagai sarana } \\
\text { pendukung dalam perkuliahan } \\
\text { IPA }\end{array}$ & Sudah Memadai & 12 & $18,75 \%$ \\
\cline { 2 - 5 } 2 & Belum memadai & 52 & $81,25 \%$ \\
\hline \multicolumn{2}{|l|}{ Total } & 64 & $100 \%$ \\
\hline
\end{tabular}

Dari 64 jawaban responden, terdapat 18,75\% responden menyatakan bahwa peralatan IPA di laboratorum PGMI sebagai sarana pendukung dalam perkuliahan IPA sudah memadai. Sedangkan $81,25 \%$ responden menyatakan bahwa peralatan IPA di laboratorum PGMI sebagai sarana pendukung dalam perkuliahan IPA belum memadai. Untuk lebih jelasnya disajikan dalam gambar berikut.

\section{Peralatan IPA di laboratorum PGMI sebagai sarana pendukung dalam perkuliahan IPA}

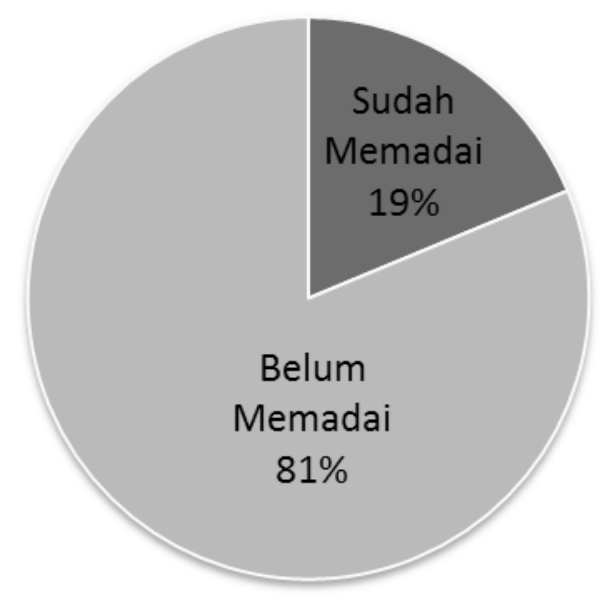

Dari 52 responden yang menyatakan bahwa peralatan IPA di laboratorum PGMI sebagai sarana pendukung dalam perkuliahan IPA belum memadai, 2 responden mengusulkan untuk menambah peralatan fisika, 3 responden mengusulkan untuk menambah peralatan biologi, 34 responden mengusulkan untuk menambah peralatan kimia, 2 responden mengusulkan untuk menambah peralatan bumi dan antariksa, sedangkan 11 responden mengusulkan untuk penambahan peralatan yang lainnya. 


\section{Kesimpulan}

Berdasarkan penilitian di atas dapat disimpulkan bahwa sebagian besar yaitu 84,13\% responden menyatakan bahwa kurikulum di Jurusan PGMI mampu membawa calon guru MI yang tangguh. Sebagian besar 95,38\% responden menyatakan bahwa Mata Kuliah IPA mampu membawa calon guru MI yang mumpuni. Sebagian besar yaitu $85,94 \%$ responden menyatakan bahwa Mata Kuliah IPA relevan dengan Materi Pembelajaran IPA di MI. Sebagian kecil yaitu 3,12\% responden menyatakan bahwa peralatan yang ada di laboratorum PGMI sebagai sarana pendukung dalam perkuliahan sudah memadai. Sebagian kecil 18,75\% responden menyatakan bahwa peralatan IPA di laboratorum PGMI sebagai sarana pendukung dalam perkuliahan IPA sudah memadai.

\section{Daftar Pustaka}

Departemen Pendidikan Nasional. (2008). Kamus Besar Bahasa Indonesia. Jakarta. Pusat Bahasa.

Imam Makruf (2015). Panduan Akademk Dan Kemahasiswaan FITK IAIN Surakarta: Fataba Press.

Jekti Prihatin. (2003). Respon Mahasiswa terhadap Pembelajaran Problem-Based Learning Dilengkapi dengan Penilaian Portofolio yang berbasis pada Lesson Study. Jember: UNEJ

Mohammad Asikin. (2003). Pengembangan Item Tes dan Interpretasi Respon Mahasiswa Dalam Pembelajaran Geometri Analitik. Semarang: FMIPA. UNES

Saifuddin Azwar. (2013). Metode Penelitian. Yogjakarta: Pustaka Pelajar Syah,Muhibbin. (2005). Psikologi Belajar. Jakarta: Raja Grafindo Persada. Soerjono Soekanto (2009). Sosiologi Suatu Pengantar. Jakarta: Rajawali Press. Subiyanto. (1998). Pendidikan Ilmu Pengetahuan Alam. Jakarta : Depdikbud.

Sudaryanto, Indrawati, dan Endang Kowara. (1998). Pengelolaan laboratorium IPA dan Instalasi Listrik. Jakarta : Depdikbud.

Suyatman. 2013. Pengembangan Perkuliahan Laboratorium IPA di Prodi PGRA. FITK IAIN Surakarta.

https://id.wikipedia.org/wiki/Respons. diakses tgl.29 Maret 2016 jam 11.22 WB

At.t| Volume. 4, No. 1, Januari-Juni 2019 